Бойко М.Г., д. е. н., проф., Ведмідь H.I., д. е. н., проф., Босовська М.В., д. е. н., проф. Київський національний торговельно-економічний університет, м. Київ, Україна Google Scholar: https://scholar.google.com.ua/citations?user=1G2_yIIAAAAJ\&hl=uk https://scholar.google.com.ua/citations?user=KPI831kAAAAJ\&hl=uk https://scholar.google.com.ua/citations?user=18idW3YAAAAJ\&hl=uk

\title{
ПАРАДИГМАЛЬНІ ТРАНСФОРМАЦЇ У ФОРМУВАННІ КОМПЕТЕНТНОСТЕЙ ФАХІВЦІВ СФЕРИ ТУРИСТИЧНОГО ТА ГОТЕЛЬНО-РЕСТОРАННОГО БІЗНЕСУ
}

Особливістю розвитку ринку готельних та ресторанних є впровадження інформаційних технологій і комп'ютерних комунікацій в усі сфери діяльності суб'єктів бізнесу, глобалізаційні процеси, загострення конкурентної боротьби на ринках праці. Окреслені тенденції обумовлюють посилену увагу до питань підготовки фахівців, які спроможні ефективно працювати в сучасних умовах.

Як свідчать аналітичні дослідження, кадровий склад суб'єктів готельного та ресторанного бізнсу м. Києва надав наступну статистику: 55\% працівників не мають спеціальної освіти; 12\% працівників протягом 2018 р. пройшли підвищення кваліфікації в контексті вимог, що висуваються до рівня професійної діяльності на ринку готельноресторанних послуг. Результати досліджень дозволяють сформулювати проблеми кадрового забезпечення туристичного бізнесу: якість підготовки фахівців не в повній мірі відповідає міжнародним стандартам; спостерігається диспропорція в структурі підготовки кадрів.

Крім означених вище проблем, зазначимо, що вступ України в Болонський процес поглибив вимоги до результату вищої освіти, що формулюється в категорії «компетентність», яка відображає суть нової парадигми результату вищої освіти.

Поняття «компетентність» [1] можна визначити як індивідуальну характеристику ступеня відповідності вимогам професії, сформованості в працівника професійних навичок, що дозволяють ефективно вирішувати професійні завдання й виконувати функції відповідно до професійно-кваліфікаційних вимог і внутрішньофір- 
мових стандартів обслуговування. Основні акценти поставлені на: практику застосування знань, вироблення операційної і технологічної складових, а не тільки на самі знання; складну інтеграційну природу результату освіти; формування особистісних якостей фахівця.

Підготовка магістрів на засадах компетентісного підходу спрямована на забезпечення якісної підготовки конкурентоспроможних висококваліфікованих професіоналів готельно-ресторанної справи, що володіють комплексом програмних компетентностей для вирішення складних задач організації господарської діяльності суб'єктів готельного та ресторанного бізнесу або у процесі навчання, що характеризується складністю і невизначеністю умов і вимог та відображають потреби ринку праці.

Особистість професійно компетентного магістра готельноресторанної справи представляється в його внутрішній цілісності, де професійне й особистісне тісно пов'язані системою цінностей. Будьякі професійні знання, перш ніж втіляться в діяльності, наповнюються ціннісним змістом, стають внутрішнім переконанням фахівця, частиною його поведінкових стереотипів. Професійно значимі індивідуальні якості виступають як атрибут, в якому зовнішні характеристики й вимоги створюють індивідуальну значимість фахівця. Виходячи 3 цього припущення, можна визначити наступні складові професійної компетенції магістра готельно-ресторанної справи: інтелектуальна; практична; иіннісно-орієнтаційна; емоційно-почуттєва.

У цьому контексті, доцільно виділити ще один, характерний для даної сфери діяльності вид компетентності - екстремальна професійна компетентність, тобто готовність до вирішення проблем в умовах, які виникають раптово і $є$ слабко прогнозованими.

Програми підготовки магістрів готельно-ресторанної справи КНТЕУ містять інтегральні, загальні та фахові компетентності. Інтегральна компетентність базується на здатності розв'язувати складні задачі організації господарської діяльності суб'єктів готельного та ресторанного бізнесу або у процесі навчання, що передбачає проведення досліджень та здійснення інновацій та характеризується невизначеністю умов і вимог. Загальні та фахові компетентності формуються компонентами освітньої програми циклу загальної і циклу професійної підготовки, що розкриває особливості підготовки фахівців для даної сфери.

Отже, навчання здобувачів вищої освіти за кваліфікацією «Магістр готельно-ресторанної справи на засадах компетентісного підходу забезпечить якісну та конкурентоспроможну професійну підготовку професіоналів у сфері готельного і ресторанного бізнесу, 
фокусується на реалізації освітніх траєкторій з прикладним, науководослідним, науково-практичним і науково-педагогічним ухилом.

\section{Список бібліографічних посилань}

1. Антонюк Л.Л., Василькова Н.В. та ін. Компетентісний підхід у вищій освіті: світовий досвід . -К.: Інститут вищої освіти КНЕУ імені Вадима Гетьмана 